\title{
O PRINCÍPIO DA VEDAÇÃO DO NE BIS IN IDEM NA CORTE INTERAMERICANA DE DIREITOS HUMANOS: CONSIDERAÇÕES SOBRE O CASO ALMONACID ARELLANO E OUTROS VERSUS CHILE
}

\author{
Emmanuelli Karina de Brito Gondim Moura Soares ${ }^{149}$ \\ Yara Maria Pereira Gurgel ${ }^{150}$
}

Recebido em: 07/12/2018

Aprovado em: 21/03/2019

\begin{abstract}
RESUMO
A efetividade da garantia e proteção aos direitos humanos é matéria de urgência, bem como o resguardo ao princípio do ne bis in idem, que através da garantia do devido processo legal, também é dispositivo de proteção aos direitos humanos. A presente pesquisa buscou demonstrar o quanto o diálogo da Comissão Interamericana de Direitos Humanos, bem como a atuação da Corte Interamericana na efetividade do diálogo, com os países da América Latina é importante para que os dispositivos de proteção aos direitos humanos previstos nos tratados tenham efetividade no contexto interno e internacional. A análise será feita com base no caso Almonacid Arellano e outros versus Chile. E através da pesquisa, buscaremos demonstrar a importância na Comissão, bem como da Corte, no resguardado aos Direitos Humanos, através da garantia do devido processo legal, da defesa pertinente, bem como da efetividade da proteção à esses direitos indisponíveis previstos na Convenção Americana de Direitos Humanos.
\end{abstract}

Palavras-chave: Direitos Humanos. Corte Interamericana de Direitos Humanos. Atendimento ao Princípio do $\mathrm{Ne}$ Bis In Idem.

\section{INTRODUÇÃO}

A presente pesquisa tem como escopo a análise do julgamento, pela Corte Interamericana de Direitos Humanos do caso Almonacid Arellano e outros versus Chile. O

\footnotetext{
${ }^{149}$ Mestranda em Direito pela Universidade Federal do Rio Grande do Norte - UFRN. Especialista em Direito Civil e Processo Civil pela UFRN. Professora da graduação em Direito da UNIFACEX, da Estácio e da UNIRN.

${ }^{150}$ Pós-doutoranda em Direitos Fundamentais pela Universidade de Lisboa. Doutora e mestre em Direito das Relações Sociais pela Pontifícia Universidade Católica de São Paulo - PUC/SP. Professora da graduação e do mestrado em Direito da Universidade Federal do Rio Grande do Norte - UFRN. Advogada.
} 
caso chegou à Corte através do envio do caso, pela Comissão Interamericana de Direitos humanos.

A Comissão Interamericana é um órgão consultivo que não tem poder jurisdicional, mas que promove a análise sobre a observância, pelos países signatários, dos dispositivos de proteção aos direitos humanos, que estão previstos na Convenção Interamericana, buscando resguardar a efetiva proteção aos direitos humanos.

Assim, a Comissão nessa análise de proteção aos direitos humanos, previstos na Convenção, recebe petições individuais, analisando e investigando, através das informações, nessas petições, se por ventura os países que compõe a OEA- Organização dos Estados Americanos, que ratificaram a Convenção, descumpriram as regras de proteção aos direitos humanos.

O caso de Almonacid Arellano e outros versus Chile se iniciou, quando no ano de 1998 as pessoas de Mario Marquez Maldonado e Elvira do Rosário Gomes Olivares, viúva de Almonacid Arellano, apresentaram uma petição alegando que o Estado do Chile violou dispositivos de proteção aos direitos humanos, quando não efetuou a investigação devida decorrente do homicídio do Sr. Almonacid Arellano em setembro do ano de 1973, período de ditadura militar no Chile, violando os dispositivos 8, 25, 1.1 e 2 da Convenção Interamericana de Direitos Humanos, quando não promoveu o devido processo legal no que tange à punição das pessoas envolvidas na prática desse homicídio.

Nesse sentido, através de uma pesquisa utilizando a metodologia bibliográfica e jurisprudencial, bem como do estudo de um caso concreto, real, se pretende demonstrar a importância da atuação da Comissão, bem como da Corte Interamericana de Direitos humanos, na concretização do resguardo aos direitos humanos, através da efetividade na aplicabilidade das normas da convenção pelos estados signatários da Convenção Interamericana de Direitos Humanos.

A Corte Interamericana de Direitos humanos, como uma instituição judiciária autônoma, aplica, bem como interpreta os dispositivos de proteção aos direitos humanos que estão previstos na Convenção.

Assim, a Corte como instituição judiciária autônoma instaura um processo de jurisdição voluntária, onde analisa o procedimento enviado pela comissão, quando ocorre o descumprimento das recomendações pelo Estado efetuado pelas recomendações iniciais feitas pela Comissão, foi o que ocorreu com o Estado do Chile no caso do Sr. Almonacid, o Chile não se manifestou sobre a implementação das recomendações dadas pela Comissão, mesmo 
após uma prorrogação postulada pelo próprio Chile, até que a Comissão Interamericana submeteu o caso à Corte.

O presente artigo busca analisar que a efetividade das medidas de proteção aos direitos humanos tem toda uma organização procedimental perante a Comissão, bem como a perante a Corte interamericana, no sentido de observar que o contraditório e a ampla defesa serão também resguardados ao Estado, quando o mesmo participará do processo, alegando em sua defesa todos os fatos pertinentes que serão apurados através de documentos e depoimentos de testemunhas.

Nesse sentido, quando forem constatadas, as violações aos direitos humanos, perpetradas pelo Estado, diante de toda uma análise de devido processo legal, em obediência à proteção aos direitos humanos, a sentença da Corte vai ser proferida para que o Estado cumpra obrigações que vão resguardar não só direitos materiais, como direitos imateriais, às vítimas, bem como à toda à sociedade, são as medidas reparatórias, que serão decididas pela Corte através de sentença e que terão força executória.

No que tange às medidas decididas por meio de sentença, no processo de sua implementação, deverão ser observados que os direitos indisponíveis de proteção aos direitos humanos serão preservados de modo geral, no sentido da proteção ao princípio do ne bis in idem, quando for resguardado, que o processo será realizado, buscando preservar sempre esse princípio aos envolvidos.

Diante dessa reflexão, será analisado o caso do homicídio do Sr. Almonacid Arellano, onde na sua apuração, o Estado do Chile não puniu efetivamente os culpados, diante disso a Corte determinou que o Estado promovesse efetivamente a garantia dos direitos humanos, em função das violações praticadas pelo próprio Estado, diante da ausência da punibilidade pela prática de um crime de lesa humanidade, não configurando tal decisão o descumprimento ao ne bis in idem.

\section{DISPOSITIVOS DO PACTO DE SAN JOSÉ DA COSTA RICA DE GARANTIA E PROTEÇÃO AOS DIREITOS HUMANOS E O ONDENAMENTO JURÍDICO CHILENO}

A Convenção Americana sobre os Direitos Humanos ou Pacto de San José da Costa Rica, diploma regional de proteção aos Direitos Humanos, foi ratificado pelo Chile em 21 de agosto do ano de 1990, tendo reconhecido no mesmo ano a competência da Corte conforme 
disposto no artigo 62 da Convenção, marco para a história chilena de proteção, em um âmbito regional, aos Direitos Humanos.

Desde então o Chile deve cumprir as determinações que visem à proteção aos Direitos do Homem e do cidadão, onde quer que ele se encontre, pois não importa o território onde o indivíduo esteja e sim a sua condição de ser humano, por tal fato, seus direitos devem ser protegidos através do ordenamento jurídico interno, bem como internacional.

Antes da internalização ao ordenamento jurídico do Pacto de San José da Costa Rica, a Constituição Chilena de 1980 já apresentava em seu artigo $1^{\circ}$, que a proteção à dignidade da pessoa humana, deverá ser uma das bases da Constituição, se não vejamos:

Art. $1^{\circ}$ Las personas nacen libres e iguales en dignidad y derechos.

(...)

El Estado está al servicio de la persona humana y su finalidad es promover el bien común, para lo cual debe contribuir a crear las condiciones sociales que permitan a todos ya cada uno de los integrantes de la comunidad nacional su mayor realización espiritual y material posible, con pleno respeto a los derechos y garantías que esta Constitución establece. (CHILE. DECRETO SUPREMO 100, 2005, artigo $1^{\text {º }}$ )

Nesse sentido, o texto do artigo primeiro da Constituição Chilena, dispõe em seu texto, que o Estado estará a serviço da pessoa humana e sua finalidade é promover o bem comum, proporcionando a todos a realização e o respeito por seus direitos e garantias.

A prevalência dos Direitos humanos deve ser percebida no contexto interno, bem como internacional. Em função dessa previsão constitucional, de proteção aos direitos humanos, se observa a adequação da Constituição do país, aos tratados de Direito Internacional de proteção aos Direitos Humanos.

O Pacto de San José da Costa Rica, em seu preâmbulo dispõe sobre a proteção a esse homem, ser universal, pela condição de ser humano, independentemente de nacionalidade, pois o território é só um detalhe. E essa proteção deverá existir no âmbito do sistema jurídico interno, bem como internacional:

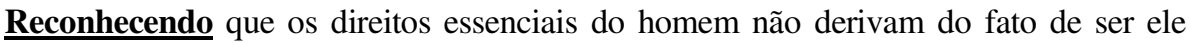
nacional de determinado Estado, mas sim do fato de ter como fundamento os atributos da pessoa humana, razão por que justificam uma proteção internacional, de natureza convencional, coadjuvante ou complementar da que oferece o direito interno dos Estados americanos; (COSTA RICA. Pacto de San José, 1969, preâmbulo)

Esse desenvolvimento de um sistema universal de proteção aos Direitos humanos tem seu impulso, no contexto mundial, no período pós segunda guerra mundial, em função de toda a repercussão negativa deixada pelo conflito, principalmente com relação a supressão dos 
direitos individuais, da dignidade da pessoa humana, justificados pela atuação excessiva dos próprios Estados.

Após o período de segunda guerra mundial, os países latino americanos, passaram por períodos de estado de exceção, em função da polarização do mundo, entre sistemas de governo capitalistas e socialistas.

Nesse sentido, a tendência latino americana, foi instalar regimes de governo ditatoriais no país, evitando a prevalência do sistema de governo socialista. Diante dessa realidade latino-americana, nesse período ditatorial, os direitos humanos passaram por situações de violações graves, demandando toda uma evolução social, constitucional, buscando reestabelecer uma proteção aos direitos humanos, que já estava presente no contexto mundial.

Essa herança ditatorial no contexto latino americano repercute até os dias atuais, pois, ainda vivemos sob os resquícios do autoritarismo nesses países, bem como de concentração de privilégios, riquezas, conhecimento, dentre outros, ou seja, ainda não temos, como latino americanos, acessível, a garantia dos direitos básicos de proteção aos direitos humanos, que são os direitos civis, políticos, econômicos e sociais, como bem dispõe a Convenção Americana sobre os Direitos Humanos em seu preâmbulo, se não vejamos:

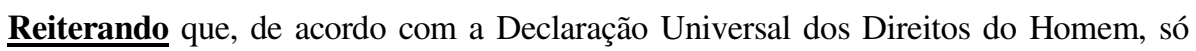
pode ser realizado o ideal do ser humano livre, isento do temor e da miséria, se forem criadas condições que permitam a cada pessoa gozar dos seus direitos econômicos, sociais e culturais, bem como dos seus direitos civis e políticos; (COSTA RICA. Pacto de San José, 1969, preâmbulo)

Ou seja, a própria Convenção Americana sobre os Direitos Humanos dispõe sobre o direito à liberdade, como uma garantia dos direitos humanos e essa liberdade será gozada, a partir do momento em que essa pessoa humana tiver resguardados os seus direitos econômicos, sociais, culturais, civis e políticos.

Nesse sentido, a Convenção Americana sobre os Direitos Humanos, vem estabelecer uma proteção à nível internacional, sendo a Corte Interamericana sobre direitos humanos uma instituição jurídica autônoma que vai aplicar e interpretar os dispositivos de proteção aos direitos humanos, exercendo função jurisdicional e ao mesmo tempo consultiva, vinculando os Estados signatários às suas decisões quando estes descumprirem as normas de proteção aos direitos humanos.

Diante dessa realidade, importante trazer os dispositivos de proteção aos direitos humanos através de uma perspectiva constitucional, latino-americano de países latino americanos, participantes da OEA-Organização dos Estados Americanos que ainda convivem 
em uma ambiência de democracia bem como de autoritarismo, mesmo apresentando em suas constituições a salvaguarda aos direitos humanos.

Essa ambiência de democracia e autoritarismo nos remonta a própria lei de anistia no Brasil, bem como a casos de violações aos direitos humanos, semelhantes ao caso do Sr. Almonacid Arellano, através do cometimento de crimes de lesa humanidade como o caso de Gomes Lund e outros versus Brasil (COSTA RICA. Corte Interamericana, 2006), que também foram apreciados pela Corte Interamericana de Direitos Humanos.

Assim, diante dessa reflexão, devemos considerar que não basta à previsão normativa de proteção aos direitos humanos, nós já possuímos no contexto legal, bem como na percepção social, a sua necessidade, precisamos efetivar na prática essa proteção aos direitos humanos, à dignidade, a partir do momento em que os Estados cumpram o seu dever no contexto interno e internacional.

\section{ATUAÇÃO DA CORTE INTERAMERICA NO CASO ALMONACID ARELLANO E A GARANTIA DO CONTRADITÓRIO E DA AMPLA DEFESA AO ESTADO DO CHILE}

Em 11 de julho do ano de 2005, a Comissão Interamericana de Direitos Humanos, doravante denominada de "Comissão" ou "Comissão Interamericana", submeteu à Corte Interamericana uma demanda contra o Estado do Chile, a qual se originou na denúncia $n^{\circ}$ 12.057, recebida pela secretaria da Comissão em 15 de Setembro de 1998. (COSTA RICA. Corte Interamericana, Almonacid Arellano Vs. Chile 2006).

A Corte, após todo o devido procedimento, perante a comissão, recebimento da petição, análise e notificação do Estado do Chile, com as devidas informações para a implementação das recomendações, bem como do prazo estipulado para que o Estado cumprisse as recomendações, condenou o Estado, Chile em sentença proferida em 26 de setembro de 2006, pela violação dos artigos 8 e 25, assim como dos artigos 1.1 e 2 da Convenção Americana de Direitos Humanos, em detrimento dos familiares do Senhor Almonacid Arellano, sua esposa, a Sra. Elvira do Rosário Gomez Olivares e dos Senhores, Alfredo, Alexis e José Luiz Almonacid Gomez, filhos do Sr. Almonacid Arellano, que foi assassinado sumariamente pelos membros do Exército do Chile na época da ditadura militar chilena, após a deposição do governo do presidente Salvador Allende. Ditadura que ocorreu, no país, entre o período de 1973 a 1990. 
O Sr. Almonacid Arellano, era professor do ensino Básico, militante do partido comunista, candidato a vereador pelo partido e era secretário provincial da Central Única de Trabalhadores e dirigente sindical do magistério.

O governo militar no Chile, no período de ditadura, efetuou uma repressão generalizada a todas as pessoas consideradas opositoras à nova política armada do Estado. Tendo sido a época mais violenta do governo, os primeiros meses em que a ditadura se instalou no país, período no qual, o Sr. Almonacid Arellano foi assassinado.

Os artigos da convenção violados pelo Estado do Chile, no caso Almonacid, se referem ao respeito às liberdades e direitos, bem como o dever de adotar dispositivos do direito interno para garantir esse respeito à liberdade de direitos, artigos 1.1 e 2 .

Os artigos 8 e 25, da Convenção, também foram violados e tratam sobre as garantias judiciais, ao devido processo legal, bem como a proteção judicial, na garantia da preservação aos direito humanos. Nesse sentido, importante trazer o teor do artigo 25 da Convenção Interamericana de proteção aos Direitos Humanos, se não vejamos:

Toda pessoa tem direito a um recurso simples e rápido ou a qualquer outro recurso efetivo, perante os juízes ou tribunais competentes, que a proteja contra atos que violem seus direitos fundamentais reconhecidos pela constituição, pela lei ou pela presente Convenção, mesmo quando tal violação seja cometida por pessoas que estejam atuando no exercício de suas funções oficiais. ; (COSTA RICA. Pacto de San José, 1969, art. 25)

No presente caso em comento, a Corte Interamericana condenou o Estado do Chile a fazer as reparações necessárias às vítimas, familiares do Sr. Almonacid, não em função do seu homicídio, ocorrido em setembro do ano de 1973, mas pela denegação do Estado, aos familiares da vítima, quanto ao acesso à justiça, na apuração desse crime e devida punição dos culpados.

A denegação da justiça ao caso Almonacid, se deu a partir do ano de 1996, quando os familiares da vítima buscaram punir os culpados, tendo o julgamento do caso sido chamado à competência da justiça militar e não da justiça, civil, comum, obtendo como resultado o arquivamento dos procedimentos investigativos e processuais criminais dos culpados pela execução extrajudicial do Sr. Almonacid, principalmente após a promulgação do Decreto Lei $\mathrm{n}^{\mathrm{o}} 2.191$, lei da Anistia, implementada no Chile, ainda na época da ditadura militar no ano de 1978.

Ao Estado do Chile foi resguardado o devido processo legal, no que tange à sua defesa, bem como as alegações de preliminares, apresentadas pelo Estado, quanto à sua submissão ao julgamento pela Corte Interamericana. 
A competência da Corte foi estabelecida, desde que o Estado do Chile ratificou a Convenção Americana, em data de 21 de agosto do ano de 1990, reconhecendo, também nesta mesma data a competência da Corte na apreciação do descumprimento pelo Estado, dos dispositivos da Convenção de proteção aos direitos humanos.

Inclusive, no caso Almonacid, o Chile alegou como defesa a exceção da incompetência ratione temporis, da Corte para reconhecer a possível violação, por parte do Estado, aos Direitos Humanos, já que a Corte, só poderia apreciar matérisa referentes à fatos ocorridos após o depósito do instrumento de ratificação pelo Estado.

Entretanto, com relação à alegação pelo Estado do Chile, quanto à incompetência da Corte para submeter o Estado à apreciação pelo descumprimento dos dispositivos de proteção aos Direitos Humanos, em função da ratificação da Convenção ter sido bem posterior ao homicídio do Sr. Almonacid, tal não prosperou, pois as violações aos direitos humanos, pelo Estado do Chile, aconteceram após a ratificação da Convenção, no caso em comento, que se classificaram quanto a omissão da apuração investigativa e punição dos culpados pelo homicídio do Sr. Almonacid, ou seja, a competência da Corte é reconhecida para apreciar a violação aos dispositivos da Convenção, no que tange à proteção aos direitos humanos.

O Estado do Chile, descumpriu todas as regras atinentes à proteção dos direitos humanos, efetuadas pelo direito interno, quando a partir do início do processo de investigação iniciado pela família do Sr. Almonacid, pela sua morte ocorrida em setembro do ano de 1973, o Estado do Chile, se omitiu em relação à investigação e punição dos culpados pelo homicídio praticado.

O Estado do Chile, também inocentou o suposto responsável pelo homicídio do Sr. Almonacid, obtendo uma sentença de absolvição no mês de janeiro do ano de 1997, pelo Tribunal Militar Chileno e tal sentença teve a sua confirmação pela Corte Marcial no ano de 1998, aplicando ao caso em comento a lei da autoanistia, lei nº 2.191 do ano de 1978.

O Estado do Chile também se omitiu, quando a Corte Suprema de Justiça do Chile, não exerceu de ofício, o controle de Constitucionalidade da lei n ${ }^{\circ} 2.191$ do ano de 1978, lei da autoanistia, ou seja, a adequação da referida lei, dos seus dispositivos aos tratados de direitos internacional de proteção aos direitos humanos, do qual o Chile é signatário, no caso em comento, da Convenção Americana sobre os Direitos Humanos.

Nesse sentido, o país teve toda a oportunidade de apresentar sua defesa perante a Corte, no entanto, restou configurado, por parte do Estado do Chile às violações dos dispositivos da Convenção, no que tange às omissões em apurar o delito praticado contra a vida do Sr. Almonacid, morto na época da ditadura militar chilena, na medida em que o 
Estado não deu à família da vítima as garantias judiciais necessárias à apuração do crime, bem como o devido julgamento aos culpados, assim como a proteção judicial, mandamentos previstos nos artigos 8 e 25 da Convenção, assim como pelo descumprimento das obrigações também previstas nos artigos 1.1 e 2, todos da Convenção Interamericana de proteção aos Direitos Humanos.

Nesse sentido, o Estado do Chile teve como obrigação efetuar medidas de reparação aos familiares do Sr. Almonacid Arellano, pelo seu assassinato em setembro do ano de 1973, medidas de reparação que vão desde a ação de Estado em promover as garantias dos dispositivos de proteção aos direitos humanos, até a reparação indenizatória, pecuniária à família da vítima, em função de todas as perdas ocorridas, em função da sua morte prematura, decorrente de atos de arbitrariedade produzidos na época da ditadura Chilena.

São reparações de cunho material, bem como imaterial, que devem ser concretizadas pelo Chile. Nesse sentido, importante transcrever a parte da decisão pela reparação, se não vejamos:

\begin{abstract}
A Corte passa, então, a determinar as medidas de reparação que considera oportunas no presente caso. Para tanto, primeiro se referirá àquelas medidas que mais se aproximam da restitutio in integrum das violações declaradas nesta Sentença, a saber: a adequação do Direito Interno à Convenção Americana e a obrigação do Estado 58 de continuar com as investigações no presente caso, identificando, julgando e sancionando os responsáveis; medidas que, ademais, fazem parte das garantias de não repetição de fatos lesivos aos direitos humanos. Em segundo lugar, a Corte se referirá à compensação econômica pelos danos materiais e imateriais que a Comissão

e os representantes alegam que os beneficiários sofreram como consequência dos fatos do presente caso. Finalmente, a Corte ordenará a publicação desta Sentença como uma medida de reparação do dano imaterial. (COSTA RICA. Corte Interamericana, Almonacid Arellano Vs. Chile, 2006).
\end{abstract}

As restituições, impostas como obrigação, ao Estado do Chile, pela Corte Interamericana de Direitos Humanos, tem cunho de restauração, bem como de proteção. Restauração que busca reestabelecer o status quo ante, o que não será mais possível pela prática do homicídio, do Sr. Almonacid, perda irreparável para a sua família, esposa e filhos, partes lesadas. Nesse sentido, a restauração se deu de forma pecuniária, indenizatória aos familiares da vítima.

A outra forma de reparação se dá no sentido de estabelecer obrigações ao Estado do Chile em adequar o seu ordenamento jurídico interno à Convenção de proteção aos direitos humanos, bem como de permanecer as investigações para que novas violações não ocorram, além de tornar pública a obrigação do Estado em cumprir à Proteção aos Direitos Humanos. 


\section{GARANTIA DO DEVIDO PROCESSO LEGAL E RESGUARDO AO NE BIS IN IDEM REFERENTE AOS CULPADOS NO CASO ALMONACID ARELLANO VESUS CHILE, NA CORTE INTERAMERICANA}

O devido processo legal é garantia não só do ordenamento jurídico interno de cada país, como o é também resguardado nos dispositivos de proteção aos direitos humanos. É o acesso a justiça, bem como a possibilidade da defesa, através do contraditório.

No presente caso em comento, os responsáveis pelo homicídio do Sr. Almonacid Arellano, foram absolvidos pela Lei da Anistia no Chile, Decreto Lei no 2.191/1978. E tal lei de Anistia, pode ser considerada como um obstáculo às investigações dos responsáveis por crimes que são considerados delitos de lesa humanidade. Ou seja, o decreto de anistia não pode impedir que os responsáveis pelas graves violações aos direitos humanos não sejam punidos, pela ausência de investigação das execuções extrajudiciais que ocorreram no Chile, na época da Ditadura Chile, tendo como uma de suas vítimas fatais, o Sr. Almonacid Arellano.

As violações aos direitos humanos, perpetradas pelo Chile nas investigações sobre o Homicídio do Sr. Almonacid Arellano, no ano de 1973, se iniciaram, quando o processo foi submetido ao Tribunal Militar, bem como através da aplicação do Decreto Lei $\mathrm{n}^{\circ}$ 2.191, anistiando os responsáveis pela prática do crime.

Tal decisão de absolvição foi mantida pela Corte Suprema no ano de 1996, seguida de mais duas absolvições advindas de processos do Tribunal Militar de Santiago, no ano de 1997 e da absolvição pela Corte Marcial no ano de 1998.

A Corte Interamericana, diante dos fatos de ausência de responsabilização criminal, dos envolvidos no homicídio do Almonacid, se pronunciou que o Estado do Chile deveria tornar sem efeito, as referidas decisões e sentenças e enviar os autos processuais à justiça ordinária, em busca do devido processo legal na seara penal, objetivando a identificação, bem como punição dos reais responsáveis pelo homicídio do Sr. Almonacid Arellano. Ou seja, é o resguardo da investigação e do julgamento dos crimes, salvaguardados pelos artigos 8 e 25 da Convenção Interamericana de proteção aos Direitos Humanos.

Nesse sentido, a Corte na sua decisão, justificou que na apuração do homicídio do Sr. Almonacid Arellano, o Chile não poderia se eximir da sua responsabilidade de como Estado, apurar os crimes de lesa humanidade cometidos, sob a justificativa de preceitos de proteção como a prescrição ao direito de punir, a irretroatividade da lei penal, nem sob a justificativa 
do princípio do Ne bis in idem, o de que ninguém poderá ser punido mais de uma vez pelo mesmo crime, fato.

O crime cometido contra o Sr. Almonacid Arellano, que vitimou também toda a sua família, é classificado como um crime de lesa humanidade e em função disso é um crime que não prescreve. Tais crimes de lesa humanidade atingem os direitos de toda humanidade, no contexto nacional, bem como internacional.

Os crimes contra a humanidade não prescrevem em função de serem considerados, no contexto internacional, como normas de jus cogens, ou seja, não precisam de uma convenção determinando a sua previsão. Nesse sentido, o Chile não pode deixar de punir um crime imprescritível, posto ser um crime de lesa humanidade e que por isso não prescreve.

Com relação ao resguardo, no caso concreto apresentado, do princípio, ne bis in idem, tal princípio é direito fundamental, direito humano estabelecido no artigo 8.4 da Convenção Interamericana de Direitos humanos, quando estabelece as garantias judiciais, se não vejamos:

1. Toda pessoa tem direito a ser ouvida, com as devidas garantias e dentro de um prazo razoável, por um juiz ou tribunal competente, independente e imparcial, estabelecido anteriormente por lei, na apuração de qualquer acusação penal formulada contra ela, ou para que se determinem seus direitos ou obrigações de natureza civil, trabalhista, fiscal ou de qualquer outra natureza.

(...)

4. O acusado absolvido por sentença passada em julgado não poderá ser submetido a novo processo pelos mesmos fatos. ; (COSTA RICA. Pacto de San José, 1969, art. 8.4.

Nas garantias judiciais, estabelecidas pela Convenção, toda pessoa deve ter o direito a defesa, ao devido processo legal, bem como o acusado, após as garantias de sua defesa, por meio do devido processo legal, absolvido, após uma sentença transitada em julgado, tem o direito de não ser submetido a um novo processo pelos mesmos fatos. É a garantia do ne bis in idem.

No que tange aos processados pelo homicídio do Sr. Almonacid, que tiveram sua absolvição declarada por meio de sentença advinda do tribunal militar, não resta outra conclusão, a não ser, considerar que não houve o devido processo legal e sim absolvição sem fundamento legal, ou mesmo arquivamento, objetivando não responsabilizar os culpados pelo homicídio do Sr. Almonacid.

Nesse sentido, a Corte se manifesta quanto à análise processual dos procedimentos de investigação e julgamento dos suspeitos de terem praticado o homicídio do Sr. Almonacid Arellano, se não vejamos: 
(....) i) a atuação do tribunal que conheceu o caso e decidiu arquivar ou absolver o responsável por uma violação aos direitos humanos ou ao Direito Internacional obedeceu o propósito de eximir o acusado de sua responsabilidade penal; ii) o procedimento não foi instruído independente ou

imparcialmente de acordo com as devidas garantias processais, ou iii) não houve a real intenção de submeter o responsável à ação da justiça.162 Uma sentença pronunciada nas circunstâncias indicadas produz uma coisa julgada "aparente" ou "fraudulenta". (....). (COSTA RICA. Corte Interamericana, Almonacid Arellano Vs. Chile, 2006).

Ou seja, o arquivamento, bem como a absolvição dos envolvidos do homicídio do Sr. Almonacid, no caso concreto, violou a responsabilização pelo crime de lesa humanidade cometido, retirando a responsabilidade criminal de quem praticou o fato, bem como não houve imparcialidade no julgamento, pois ocorreu no Tribunal militar e não na justiça comum. Assim, como bem determina a reflexão da Corte, a referida sentença de absolvição ou arquivamento, foi proferida em circunstâncias que determinam uma coisa julgada aparente, eivada de vícios que a tornam inválida. Por isso não ser cabível a defesa da garantia do ne bis in idem.

Diante do caso, a Corte se manifestou, no sentido de que, a apresentação de novos fatos, no cometimento de crimes de lesa humanidade, podem demandar um novo procedimento criminal, pois o bem jurídico a ser tutelado, não é só o direito à vida, bem como à dignidade do indivíduo, mas também um direito a vida de toda a humanidade no contexto internacional, proteção advinda do jus cogens.

Nesse sentido, importante apresentar o posicionamento da Corte:

(...) as investigações podem ser reabertas, inclusive se existir uma sentença absolutória com qualidade de coisa julgada, posto que as exigências da justiça, os direitos das vítimas e a letra e o espírito da Convenção Americana afastam a proteção do ne bis in idem. 155. No presente caso, cumprem-se duas hipóteses indicadas. Em primeiro lugar, a causa foi levada por tribunais que não possuíam a garantia de competência, independência e imparcialidade. Em segundo lugar, a aplicação do Decreto Lei $n^{\circ} 2.191$ consistiu em subtrair os supostos responsáveis da ação da justiça e manteve

impune o crime cometido contra o senhor Almonacid Arellano. Consequentemente, o Estado não pode se amparar no princípio de ne bis in idem para não cumprir o ordenado pela Corte (par. 147 supra). . (COSTA RICA. Corte Interamericana, Almonacid Arellano Vs. Chile, 2006, p. 147).

Assim, a garantia do direito humano ao ne bis in idem, que tem resguardo no artigo 8.4, das garantias judiciais, da Convenção Interamericana de Direitos Humanos, não deve ser alegada como matéria de defesa, no caso em comento, posto não ter havido a devida instrução criminal, com imparcialidade a determinar uma absolvição ou arquivamento de um processo, que não apurou como deveria, um crime de lesa humanidade, punindo efetivamente as envolvidos no caso. 
$\mathrm{O}$ ne bis in idem tem existência histórica que remonta às civilizações clássicas. Nesse sentido, importante trazer comentários da professora Keity Saboya, em seu livro, quando a mesma faz referência a sua origem e significado:

\begin{abstract}
Entre os pensamentos mais difundidos sobre a origem do princípio do ne bis in idem, prevalece a percepção que vincula seu nascimento ao direito romano, indicando Arturo Rocco que a expressão bis de eadem re agere ne liceat, como princípio, era conhecido inicialmente, teve sua primeira referência, pelo menos no que diz respeito à persecução punitiva, na Lei da XII Tábuas no final do Século IV a.c. Costuma-se atribuir a origem desse princípio à edição da Lex repetundarum, aproximadamente entre os anos de 123 a 122 a.c., no direito romano, na qual se fixou que a sentença poria fim ao processo, não se admitindo nova ação pelos mesmos fatos. (SABOYA. 2014, p. 14 )
\end{abstract}

O princípio de garantia de direito humano, ao ne bis in idem, busca salvaguardar o indivíduo de não ser punido pelos mesmos fatos mais de uma vez. Ou seja, a sentença poria fim ao processo estabelecendo uma punição, não havendo a possibilidade de nova incriminação sobre os mesmos fatos.

É a garantia de que a punição não se perpetue, do devido processo legal e da garantia do resguardo à coisa julgada. Nesse sentido, também se manifesta novamente a professora Keity quanto ao procedimento.

\footnotetext{
Com a aplicação do princípio do ne bis in idem nos moldes concebidos pelo direito romano, assegurava-se que a "coisa" obtida em virtude de uma ação não poderia ser reclamada uma segunda vez, por restar "esgotada ou consumida", expressando-se, dessa forma, o caráter marcadamente processual desse princípio pela proibição de ajuizamento e/ou esgotamento de um segundo processo pelos mesmos fatos. (SABOYA. 2014, p. 34)
}

No presente caso, em função de todo o significado do princípio do ne bis in idem, restou configurada a coisa julgada "aparente", ou "fraudulenta", identificada pela decisão da Corte, na apuração do processo criminal dos acusados pelo homicídio do Sr. Almonacid Arellano, com o resultado da absolvição dos mesmos, o que não obedeceu o devido processo legal, bem como a instrução criminal. Assim, não resta configurada, no caso em comento, uma dupla punição, quando a Corte decide, através de sentença, que o Estado do Chile deverá dá continuidade ao processo através de novas investigações pelo crime de homicídio cometido contra o Sr. Alminacid, com fins de efetivamente responsabilizar os culpados.

Assim, o Estado do Chile deve cumprir o seu dever de investigar e punir os acusados pela prática dos crimes de lesa humanidade, através do suporte de suas instituições que devem apresentar facilidades nas informações para que os autores do crime cometido contra o $\mathrm{Sr}$. Almonacid recebam as devidas punições, bem como não só a família da vítima tenha acesso 
às informações do procedimento investigativo e processual, como toda a população chilena, posto que o interesse na defesa do direito à vida é universal, ultrapassa as fronteiras do país.

\section{CONSIDERAÇÕES FINAIS}

A pesquisa em comento buscou trabalhar a garantia e proteção aos Direitos humanos através da atuação da Corte Interamericana de Direitos Humanos em sua atuação Regional, o que no presente caso, no contexto latino americano, se apresenta de uma forma extremamente necessária e importante.

A nossa América Latina é um continente marcado por muitas desigualdades e injustiças sociais, inclusive no nosso contexto regional, apresentamos muitas peculiaridades regionais também, onde alguns países também apresentam graus de desenvolvimento diferentes uns dos outros.

Entretanto, uma situação é perceptível, os países da América Latina, após o período da segunda guerra mundial, passaram por processos ditatoriais de governo, mesmo após o fim da segunda guerra mundial, onde depois das atrocidades cometidas contra os direitos humanos, o contexto mundial de proteção se modificou, nesse sentido, com fins de perceber a necessidade de uma proteção aos Direitos Humanos e a dignidade humana de forma global. Entretanto, nós latino americanos, tivemos que amargar processos ditatoriais em nossos países em função da busca por uma hegemonia política e social.

Entre o socialismo e o capitalismo, o capitalismo se torna vencedor, mas a custa de muitas vidas sobre o solo latino americano. Esse período ditatorial não existe mais em forma de Estado, mas os resquícios de autoritarismo, privilégios e diferenças sociais ainda existem, são bem presentes nos países da América latina. Em função dessa realidade, a importância dos tratados de Direito Internacional, bem como da Comissão Interamericana de Direitos Humanos e da Corte Interamericana de Direitos Humanos, com fins de aplicar, interpretar e efetivar o cumprimento das normas de proteção aos direitos humanos.

Com base nessas reflexões, se buscou demonstrar através da apuração do caso Almonacid Arellano e Outros versus Chile, o quanto os países, da América Latina, ainda precisam evoluir, no sentido da aplicabilidade da proteção aos direitos humanos, pois mesmo com a previsão normativa de direito interno e no contexto internacional, da proteção à dignidade humana, os direitos indisponíveis à dignidade, que são direitos fundamentais ao ser humano, são violados a todo o momento. 
Alguns casos que são levados à Comissão, são apreciados pelo órgão consultivo e até chegar à apreciação da Corte, o país ainda pode aceitar às recomendações de adequação aos dispositivos de proteção aos direitos humanos, entretanto, mesmo assim, muitos dos casos chegam à Corte, para que as medidas de proteção aos direitos humanos sejam protegidas e concretizadas de fato.

Também buscamos comprovar, através da presente pesquisa, que os Estados, bem como às partes, que buscam a tutela aos seus direitos indisponíveis, tem a garantia ao devido processo legal, quando o caso demanda a apuração pela violação dos dispositivos de proteção aos direitos humanos, perpetradas pelo Estado. E através do contraditório e da ampla defesa, os Estados podem apresentar todas as justificativas e comprovações da sua atuação, assim como às partes, vítimas, também será resguardada a apresentação da defesa, e oportunidades de apresentar comprovações do da discussão à violação dos direitos humanos que está em análise.

Esse devido processo legal, resguarda mais um princípio de garantia aos direitos humanos, previsto na Convenção Americana de Direitos humanos, Pacto de San José da Costa Rica, em seu artigo 8.4, que determina o resguardo ao princípio do ne bis in idem, tal princípio resta preservado e se demonstrou tal respeito na análise da sentença proferida pela Corte no caso do homicídio do Sr. Almonacid Arellano, tendo como resultado da sentença, a condenação do Estado do Chile pelos danos materiais e imateriais, sofridos não só pela família do Sr. Arellano, como também toda a humanidade, que teve através do seu caso, os direitos violados.

O que se extrai da pesquisa é que ainda temos muito que evoluir como Estado e como sociedade latino americana, na conscientização da concretização dos direitos humanos, direitos que devem ser resguardados a todo indivíduo, independentemente de raça, sexo, nacionalidade, orientação sexual, convicções políticas, filosóficas, dentre outros, pois estamos resguardando os direitos humanos e a dignidade desse ser individual, que é a mesma, onde quer que esse indivíduo esteja, independentemente do território.

Assim, ainda temos que evoluir muito, mais os passos e os procedimentos já estão sendo dados, através da Comissão e da Corte Interamericana de Proteção aos direitos Humanos e isso já é muito importante, pois o contexto político, social e econômico da América Latina, ainda demanda uma proteção especial e mais cuidadosa, quanto a avaliação e efetividade na aplicação das normas de resguardo aos direitos humanos. 


\section{REFERÊNCIAS}

BARROSO, Luis Roberto Barroso. A Dignidade da Pessoa Humana no Direito Constitucional Contemporâneo. A Construção de um conceito jurídico à luz da jurisprudência mundial. Fórum: 2013.

BERNARDES, Edilene Mendonça. Direitos Humanos no Brasil: uma análise da demanda brasileira junto à Comissão e à Corte Interamericana de Direitos Humanos no período de 2003 a 2010. <direitoestadosociedade.jur.puc-rio.br/media/3artigo40.pdf> Acesso em: 28/09/2018.

Chile, Constituição

Chilena.

https://www.camara.cl/camara/media/.../constitucion_politica.pdf> Acesso em: 28/09/2018.

Caso Gomes Lund e $\quad$ Outros versus $\quad$ Brasil.< www.corteidh.or.cr/docs/casos/articulos/seriec_219_por.pdf> Acesso em: 28/09/2018.

CARREAU, Dominique. Direito Internacional/Dominique Carreau, Jahyr-Philippe Bichara. Rio de Janeiro: Lumen Juris, 2015.

COSTA, Helena Regina Lobo da. DIREITO PENAL ECONÔMICO E DIREITO ADMINISTRATIVO SANCIONADOR $n e$ bis in idem como medida de política sancionador integrada. < dpi.usp.br/single.php?_id=002462095> Acesso em: 28/09/2018.

CORTE_IDH_ALMONACID_ARELLANO.

https://www.cidh.oas.org/basicos/portugues/c.convencao_americana.htm> Acesso em: 28/09/2018.

$\begin{array}{lllll}\text { Convenção } & \text { Americana } & \text { sobre } & \text { Direitos } & \text { Humanos.< }\end{array}$ https://www.cidh.oas.org/basicos/portugues/c.convencao_americana.htm> Acesso em: 28/09/2018.

INGO, Wolfgang Sarlet. Dignidade da Pessoa Humana e Direitos Fundamentais. 4 ed. Porto Alegre: Livraria do Advogado, 2006.

GOLDSHMIDT, Fábio Brun. Teoria da Proibição de Bis In Idem no Direito Tributário e Sancionador Tributário. São Paulo: 2014.

PIOVESAN, Flávia. Direitos humanos e diálogo entre jurisdições. In Revista Brasileira de Direito Constitucional - RBCD n.19 - jan/jul, 2012. 
SABOYA, Keity. Ne Bis In Idem. História, Teoria e Perspectivas. Rio de Janeiro: Lumen Juris, 2014.

SABOYA, Keity. Dimensões do princípio do $\mathrm{Ne}$ Bis In Idem. <bdtd.ibict.br/vufind/Record/UERJ_> Acesso em 28/09/2018.

THE PRINCIPLE OF THE SEAL OF THE NE BIS IN IDEM IN THE INTERAMERICAN COURT OF HUMAN RIGHTS: CONSIDERATIONS ON THE CASE OF ALMONACID ARELLANO AND OTHERS VERSUS CHILE

\begin{abstract}
The effectiveness of the guarantee and protection of human rights is a matter of urgency, as well as the safeguarding of the principle of ne bis in idem, which, through the guarantee of due process of law, is also a protection of human rights. The present research sought to demonstrate how important the dialogue between the Inter-American Commission on Human Rights and the Inter-American Court's intervention in the effectiveness of the dialogue with the countries of Latin America is important so that the human rights protection provisions of the treaties are effective in the internal and international context. The analysis will be made based on the case of Almonacid Arellano and others versus Chile. And through research, we will seek to demonstrate the importance in the Commission, as well as of the Court, in the protection of Human Rights, through the guarantee of due process of law, of the pertinent defense, as well as of the effective protection of these unavailable rights provided in the American Convention of Human rights.
\end{abstract}

Keywords: Human rights. Inter-American Court of Human Rights. Attention to the Principle of $\mathrm{Ne}$ Bis In Idem. 